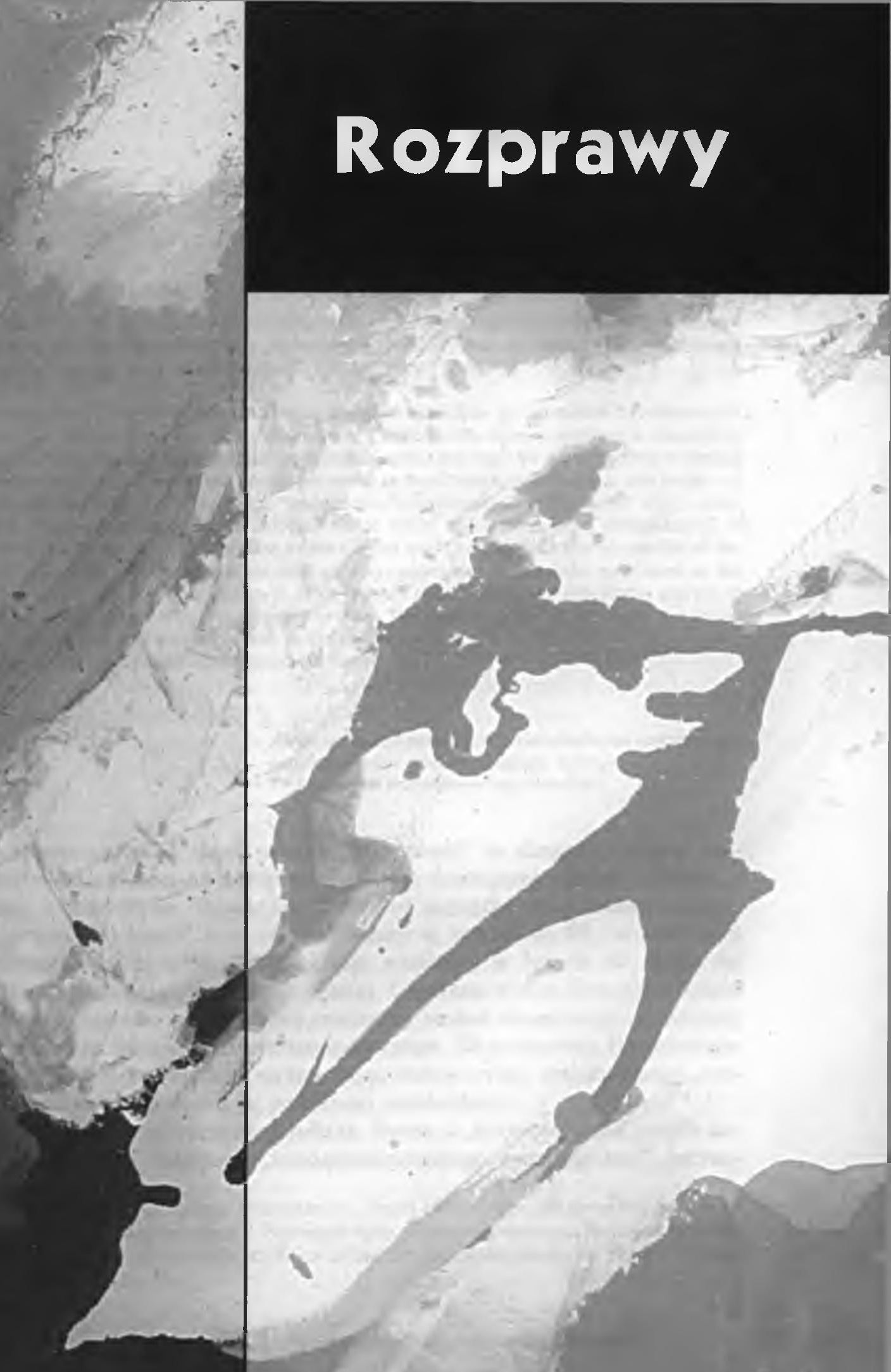


MW61010) 


\section{Czy jest możliwa inna historia teorii} (literatury)?

ABSTRACT. Ulicka Danuta, Czy jest możliwa inna historia teorii (literatury)? [ls another history of the theory (of literature) possible?]. "Przestrzenie Teorii" 7, Poznań 2007, Adam Mickiewicz University Press, pp. 9-29. ISBN 978-83-232177-2-5. ISSN 1644-6763.

This article binds several problems in which literature specialists are interested: in reference to the famous disputes about the theory of literature it indicates the need to redefine it, proposes is conceptualisation as a cultural opinion (utterance), justifies this need by the analysis of historical factual realisations of "theory" and conditions which reduced (monologised) them, and finally - it refers to the question of actuality of the "post-modern breakthrough" and the "turns" which announce it. The documentation of the proposed theses which revise the existing interpretations of history of the theory is being searched in the Central and East European literary studies of the beginning and the first decades of the 20th century, which has always been considered as the founding one for the discipline, however, since recently also as the source one for the analysis of the status of the utterances (opinions) expressed in it. The question asked in the title of this article about the possibility of another history of the theory resolves just in reference to the previous, nowadays mechanically enlivened projects of theory.

- Ale po czym pan poznaje, że jakieś dzielo jest nowoczesne? - zapytat wreszcie przewodniczqcego komisji.

- Po tym, że nie przypomina czegokolwiek ${ }^{1}$.

„Literaturyzacja” bądź nawet „literackość” to diagnozy często stawiane w odpowiedzi na pytanie o kondycję dzisiejszej wiedzy, również wiedzy o literaturze. Towarzyszyły one od początku długoletniej kampanii „przeciwko teorii”, rozpoczętej jeszcze w końcu lat 60., w okolicach pamiętnego roku 1966, i szczególnie nasilonej w latach 80. Echa tej kampanii rozlegają się jeszcze i dzisiaj. Używane w niej formuły wiążące literaturoznawstwo z literaturą zawierały ważne obserwacje i postulaty pod adresem dyskursu literaturoznawczego. Eksponowały literaturogeniczne przemiany wiedzy, wyznaczając antywzorzec zniesławianej „teorii" i wskazując kierunek jej pożądanej przebudowy.

Postulaty te zdominował jednak frazes o "terroretyzmie”, czyli imperialistycznych zakusach "fundacjonistycznego esencjalizmu”, jedyno-

1 Z rozmowy francuskiego dziennikarza, Paula Geraldy'ego, na paryskiej Światowej Wystawie Sztuk Dekoracyjnych i Przemysłowych, z przewodniczącym komisji kwalifikacyjnej Wystawy („L'Illustration” 1925, nr 25.09; cyt. za: „Kolekcja Sztuki Polskiej i Swiatowej" 2006, nr 118). 
władczo jakoby panującego dotąd na całym obszarze teoretycznych badań literackich. Jak to zwykle w bojowych wystąpieniach bywa, znaczenie pojęcia „teoria” szybko się w nich rozmyło, by służyć orężem armiom zgromadzonym pod różnymi sztandarami, tyleż przeciwników strukturalizmu, fenomenologii i hermeneutyki, co dekonstrukcji i poststrukturalizmu. „Teoria”, utożsamiona w tych bojach ze wszystkimi wymienionymi orientacjami, jednako jakoby reprezentującymi „naukę”, „myślenie systemowe”, naganną „metafizykę przedstawienia” i „reifikację sensu”, wyszła $\mathrm{z}$ nich jednak, nawet jeśli nie zwycięsko, to bez szwanku. Zyskała natomiast cenną możliwość spojrzenia na własną historię $\mathrm{z}$ innej perspektywy, a tym samym zdystansowania się i do stawianych oskarżeń, i do samej siebie, do własnego stylu, zarówno języksowego, jak myślowego.

Dystans ten przejawiał się od połowy lat 60 . w spektakularnym zarzucaniu prototypowo naukowych sposobów artykulacji literaturoznawczych rozpoznań i wypracowywaniu artykulacji nowych - przynajmniej na tle tych pierwszych. Właśnie te uchodzące za nowe sposoby teoretycznoliterackiego mówienia, oznaczane dodatkowo metatekstowymi wskaźnikami „para” lub „post”, markującymi niechlubny komentarz „scjentystyczny”, zostały objęte ogólną formułą „literaturyzacji”. Pozwoliła ona zobaczyć w „prozie intelektualnej” - narrację, którą zarówno ze względu na kompozycję, jak specyfikę referencji można traktować na równi $\mathrm{z}$ fikcją, a w jej autorach zidentyfikować „pisarzy” (twórców powieści, nowel, anegdot bądź autobiografii). W analizach ich pisarstwa szczególnie często pojawiała się kategoria nieostrości. Jej zastosowanie, inspirowane współbieżnymi diagnozami zmącenia, hybrydyczności, a nawet zagłady tradycyjnych gatunków na rzecz rozmytych, synkretycznych "genrów” mowy, wyzwalało mnożenie określeń quasi-genologicznych. Sygnalizowały one stan poetologicznej (funkcjonalnej), a także dziedzinowej (instytucjonalnej) nieprzynależności pisarstwa teoretycznego. W przypadku tekstu teoretycznoliterackiego „mętność” oznaczała jego już nie tylko pograniczność wobec „literatury”, ale i nieodgraniczalność od niej.

Nie oceniając trafności tego typu diagnoz, niearbitralnych przecież, odnoszących się do rzeczywistych praktyk literaturoznawczych, zgodnych też $\mathrm{z}$ obserwacjami przemian dyskursywnych $\mathrm{w}$ ościennych dziedzinach wiedzy i w nich znajdujących wsparcie - jedno można stwierdzić z całą pewnością: poczynając od połowy XX stulecia refleksja o poetyce (stylistyce, kompozycji, retoryce, postaci gatunkowej) tekstów literaturoznawczych zaczęła coraz mocniej konkurować z tradycyjnymi ich uporządkowaniami z punktu widzenia metod (szkół, doktryn, orientacji i kierunków) bądź tematów i problemów. Ta zmiana podejścia, znacznie głębsza i brzemienna w poważniejsze konsekwencje, niż po prostu zmiana $z$ „co" na ,jak”, oraz towarzysząca jej zmiana usytuowania litera- 
turoznawstwa (już nie w świetle filozofii, socjologii, psychologii czy estetyki, ale twórczości literackiej i jej teoretycznych konceptualizacji), trwa dostatecznie długo, by ją pominąć. Obejmuje też zbyt wiele innych niż literaturoznawcze tekstów kultury badanych w dyscyplinach tradycyjnie zwanych humanistycznymi, by ją zlekceważyć.

Zasygnalizowana zmiana nastawienia dotyczy bowiem całej bodaj refleksji naukoznawczej w 2. połowie XX wieku, kształtującej się pod silnym wpływem kulturalizmu i konstruktywizmu (psychologicznego, socjologicznego), wchłaniającej efekty tzw. „zwrotu lingwistycznego” i kolejnych „zwrotów” wyłonionych w jego orbicie. W refleksji tej poczesne miejsce zajmuje analiza wypowiedzi naukowych prowadzona na wzór analizy wypowiedzi literackich, w języku i terminach wypracowanych w 1. polowie XX wieku specjalnie dla tych ostatnich, $\mathrm{z}$ uwzględnieniem używanych wobec nich kategorii (takich przede wszystkim jak specyfika odniesienia, fikcyjność, organizacja stylistyczna, retoryczna i gatunkowa, podmiotowa modalizacja, narracja, fabuła, punkt widzenia, kompozycja, charakter performatywny). Już samo zastosowanie literaturoznawczego słownika i właściwego, rezerwowanego dotąd dla literatury stylu myślenia do tekstów prototypowo nieliterackich musiało pociągnąć za sobą rewizję ich dyskursywnego usytuowania i reinterpretację pełnionych przez nie funkcji. W większości nauk społeczno-humanistycznych rozstrzygnięcia wnoszone za sprawą przejętych kategorii zostały przyjęte jako bezdyskusyjne pewniki. Literaturoznawstwo traktowane jako literatura nie stanowi pod tym względem wyjątku, wpasowuje się raczej znakomicie w stabilny już porządek „tekstowego świata”, który stał się naturalnym środowiskiem wytworów kultury. Tworzy w jego universum jeden ze światów aktualnych: „świat literackości”, czy też, jak będę mówić, „literaturoznawczych dyskursów możliwych".

Jednakże w literaturoznawstwie, jeśli porównać je $\mathrm{z}$ historiografią, socjologią, psychologią, antropologią, kulturoznawstwem, ekonomią, rzecz wygląda szczególnie. Formuła „iteraturyzacji”, odnoszona do jego wyodrębnionej fazy postteoretycznej (ponowoczesnej, pomodernistycznej) i stosowana ze względu na obserwacje przeobrażeń stylistyczno-gatunkowych „pisarstwa literaturoznawczego", jakie wówczas miały nastąpić, jest, historycznie rzecz biorąc, zbyt wąska. Kondycja określana jako ponowoczesna zdaje się $\mathrm{w}$ ogóle dotyczyć badań nad literaturą względnie słabo. Nie tylko dlatego, że pozostawanie w środowisku tekstowym, odniesienie do tekstów, a nie do „obiektów” niezależnych od świadomości i języka, jest dla nich tak zwyczajne, że przypominanie o tym trąci powtórką abecadła (acz zarazem tłumaczy ich centralną rolę w tekstowym świecie kultury). Abecadło to musiały sobie przyswoić inne dyscypliny kulturoznawcze, w 2. połowie XX wieku ostatecznie rozstające się $\mathrm{z}$ ilu- 
zją referencji do „obiektywnych faktów”; wiedza o literaturze nauczyła się go w pierwszych dekadach stulecia. Literaturoznawstwo nie znalazło się w kondycji zwanej ponowoczesną nie dlatego także, by teksty literaturoznawcze wyłamywały się $\mathrm{z}$ tekstowych $\mathrm{i}$ ideowych przemian dokonujących się $\mathrm{w}$ różnych dziedzinach wiedzy. Przeciwnie, uczestniczyły w nich aktywnie, nie jeden raz energicznie je inicjując. Sama machina przemielająca wypowiedzi „od nauki do literatury” właśnie w literaturoznawstwie została przecież wynaleziona i w nim po raz pierwszy zastosowana. Jeśli więc cokolwiek może dziwić, to chyba to jedynie, że obecnie działa ona na zasadzie perpetuum mobile - że wypracowana w literaturoznawstwie teoria stała się w końcu narzędziem jego własnego opisu.

Najważniejsza przyczyna odmienności tkwi gdzie indziej. Polega ona na tym, że przemiany uznawane za symptomatyczne dla ponowoczesności zaczęły się w literaturoznawstwie znacznie wcześniej niż w fazie "post", bo na samym początku wyłaniania się jego nowoczesnej (modernistycznej) postaci, to znaczy na przełomie wieku XIX i XX i w trzech pierwszych dekadach wieku XX. Stało się to za sprawą dobrze wówczas przeprowadzonych, wnikliwych i wszechstronnych dyskusji na temat przedmiotu i metody wiedzy o literaturze, toczących się głównie - trzeba to podkreślić od razu - na obszarze środkowo- i wschodnioeuropejskim. I rzecz nie $w$ tym jedynie, że $\mathrm{w}$ tych dyskusjach wykrystalizował się „obiekt” nowej, rodzącej się dopiero dyscypliny - taki „obiekt”, którego owoczesna ontologia dopiero się domyślała: nieempiryczny, intencjonalny, przynależny do „trzeciego królestwa” bytów, wyróżnionych przez „współczynnik humanistyczny”, swoisty „biernik” myśli i wypowiedzi, zarazem „zastany” w aktach poznawczych i w nich tworzony („zadawany”).

Tego typu charakterystyki owego obiektu, wskazujące na jego relacyjną naturę, często nieporadne i nieprecyzyjne, wypracowywane z wyraźnym wysiłkiem przekraczania powszechnie używanego naonczas słownika, ale niezdolne jeszcze uwolnić się od niego, można znaleźć także w obszarze ówczesnej refleksji germańskiej i romańskiej. Rzecz nie tylko w tym, że zarazem formowały się stosowne do specyfiki tak definiowanego obiektu metody badawcze, odpowiadające jego nie-gotowości, niedefinitywności i relacyjności, historyczności i faktyczności (konkretności), a zarazem empirycznej nieuchwytności. Ranga debat środkowoi wschodnioeuropejskich $\mathrm{z}$ przełomu XIX i XX oraz początku XX wieku polega przede wszystkim na wyakcentowaniu, iż obiekt ten ma prymarnie tekstowy charakter, co znaczyło - że jest to obiekt słowny, wypowiedziowy, nierozerwalnie powiązany $z$ tym, co dookreśla wszelką wypowiedź: $\mathrm{z}$ jednej strony $\mathrm{z}$ każdorazowo aktualizowanymi regułami jej budowy, $\mathrm{z}$ drugiej zaś $\mathrm{z}$ okolicznościami, w jakich powstała, $\mathrm{z}$ podmiotem, za sprawą którego powstała, oraz z podmiotami, za których sprawą 
uzyskała określony status dyskursywny, że wreszcie - i znów: jak każda wypowiedź - w nieskończoność dopracowuje się swego znaczenia, archiwizując znaczenia jedne, historycznie je na sobie nawarstwiając i kulturowo utrwalając („gramatykalizując"), a zarazem wchłaniając znaczenia nowe, w wyniku których te wcześniejsze wciąż podlegają kolejnym reinterpretacjom.

Takie ujęcia znajdziemy zarówno u środkowo- i wschodnioeuropejskich językoznawców (Lwa Szczerby, Jewgienija Poliwanowa) i u literaturoznawców: Wiktora Szkłowskiego, Romana Jakobsona, Jurija Tynianowa i Jana Mukařovskiego, Romana Ingardena i Konstantego Troczyńskiego, Konstantego Wóycickiego, Dawida Hopensztanda i Stefana Żółkiewskiego, Juliusza Kleinera, Zygmunta Łempickiego, Stefanii Skwarczyńskiej, Wiktora Weintrauba i Stefana Adamczewskiego, u Michaiła Bachtina, Olgi Freudenberg i Jurija Lotmana, Michała Głowińskiego, Aleksandry Okopień-Sławińskiej, Janusza Slawińskiego. W ich rozważaniach złożona problematyka wypowiedzi „zastanej” i „zadanej”, istniejącej bezwzględnie obiektywnie, ale zarazem konstruowanej w aktach jej poznawania, jednocześnie „wewnętrznej” i „zewnętrznej” wobec tych aktów, wytworzonej przez realny podmiot twórczy, ale też oderwanej od bezpośredniej więzi z nim, zrozumiałej pod warunkiem odniesienia do kontekstu, który wszakże jednocześnie jest w niej neutralizowany, uchwytnej dzięki aktywizacji wielorakich konwencji, które jednocześnie są w niej znoszone, a tym samym konfigurowane na nowo - doczekała się precyzyjnych, wielostronnych analiz. $\mathrm{Z}$ punktu widzenia rozwiązań zarysowanych $\mathrm{w}$ tych analizach różnice między tradycyjnie wydzielanymi „Szkołami”, dzielące „neoidealistów”, „formalistów”, „fenomenologów”, „dialogistów”, „strukturalistów” i „semiotyków”, z perspektywy stulecia $\mathrm{z}$ okładem są - powtórzę: $\mathrm{z}$ tego punktu widzenia - zaniedbywane.

Zaniedbywane tym bardziej, że owa tekstowo-wypowiedziowa definicja przedmiotu literaturoznawczych poszukiwań zawierała także przypisywane mu funkcje - w modernizmie środkowo- i wschodnioeuropejskim w żadnym razie nie czysto estetyczne. Estetyczna jakość wypowiedzi, wiązana $\mathrm{z}$ poszukiwaniami niepowtarzalnego literackiego idiomu, którą fetyszyzowali późniejsi komentatorzy nowoczesnego pisarstwa literaturoznawczego, albo krytycznie upatrując w niej postulatów separacji sztuki literackiej wobec powinności społecznych, albo wyzwolicielskiego programu prawdziwie naukowych, pewnych i nierelatywistycznych badań nad nią, była jakością - po pierwsze - polemiczną, po drugie zaś służebną.

Polemiczną - bowiem stanowiła $\mathrm{z}$ jednej strony argument $\mathrm{w}$ dyskusji wobec zastanego literaturoznawstwa uprawianego duchu historii idei, z drugiej zaś - narzędzie obrony przed niebezpieczeństwem zawłaszczenia wyników literaturoznawczego poznania przez oficjalne ideologie. To 
przede wszystkim dlatego formaliści rosyjscy odrzucali filozofię sztuki symbolistów i analizy szkoły historyczno-kulturowej (skądinąd pod wieloma względami im bliskie), zrywając flagę powiewającą nad warownią, jak to barwnie ujął Szkłowski, a formaliści polscy - „duchologię" i „ekspresjonizm”. Projekty te, niezależnie od intencji ich twórców, mogły bowiem dostarczać artystyczno-intelektualnego wsparcia dla idei społecznych i politycznych ocenianych jako etycznie naganne, bywały też podchwytywane i dla ich umocnienia wykorzystywane. Kompromitację takiego podatnego na zawłaszczenie literaturoznawstwa przypieczętowały nacjonalistyczna historia literatury w Niemczech i wyprowadzony z idei Trzeciego Renesansu, zinterpretowanych w duchu mocarstwowego imperializmu, program oficjalnego literaturoznawstwa marksistowskiego w Rosji sowieckiej. Takie użycia zdarzały się także w międzywojennej i powojennej nauce o literaturze polskiej. Nie znaczy to jednak, że literaturoznawstwo nowoczesne uznało wartość estetyczną za wartość finalną.

Wartość ta była bowiem zarazem wartością służebną - wobec zadań stawianych owej na pozór tylko „czystej” wiedzy literaturoznawczej: wydobywania $\mathrm{z}$ literatury walorów krytyczno-emancypacyjnych (formalizm rosyjski), swoiście, „epifanijnie”, poznawczych, nakierowanych na artykulację podmiotowego nastawienia wobec świata (neoidealizm), „metafizycznych", traktujących dzieła jako szczególnie nośną reprezentację doświadczanych wartości - egzystencjalnych i etycznych (fenomenologia), religijnych (Bachtin), społeczno-komunikacyjnych, odwzorowujących międzyludzkie relacje $\mathrm{w}$ określonych historycznie wspólnotach kulturowej (międzywojenny formalizm polski, strukturalizm praski, semiotyka), a zarazem mających moc regulatywną wobec nich. Takie nastawienie poświadczają również biografie kreatorów literaturoznawstwa środkowoi wschodnioeuropejskiego i dramatyczne losy ich spuścizny, związane $\mathrm{z}$ autentycznie tragicznymi wyborami światopoglądowymi.

O tych właśnie funkcjach wypowiedzi literackiej mówiły od zarania swojej modernistycznej historii opowieści literaturoznawcze, przynajmniej - nie dość podkreślania tego - na obszarze wschodnio- i środkowoeuropejskim. W dziejach badań literackich figurują one jako opowieści "neoidealistyczne”, „hermeneutyczne”, „formalistyczne”, „fenomenologiczne”, „strukturalistyczne”, „semiotyczne”. Najważniejsza różnica, jaka między nimi zachodzi, nie polega wszakże ani na odmienności opcji metodologicznych, ani nawet na usytuowaniu w układzie odniesienia do sąsiednich dyscyplin i związanym $\mathrm{z}$ jego wyborem typem argumentacji. Wprawdzie twórcy opowieści neoidealistycznych, hermeneutycznych i fenomenologicznych odwoływali się głównie do autorytetu filozofii, zaś autorzy ujęć formalistycznych, strukturalistycznych i semiotycznych szukali wsparcia przede wszystkim w lingwistyce, niezależnie jednak od sił, 
w których polu się lokowali i pracowali, wszyscy bez wyjątku na równi wiązali funkcje wypowiedzi literackiej z samym jej słownym ukształtowaniem. To oni w istocie zainicjowali „zwrot lingwistyczny”, obwieszczony pół wieku później, przygotowali też dla niego użyteczne i wciąż używane oprzyrządowanie.

A mówiąc „o" owych funkcjach i zarazem ostrząc narzędzia mówienia o nich, udoskonalając je bądź w odwołaniu do okalającej filozofii, bądź nowoczesnych kierunków we współczesnym językoznawstwie, autorzy modernistycznych opowieści literaturoznawczych zarazem te funkcje odkrywali, wytwarzali i narzucali. Jawnie - w wypowiedziach uciekających się do formuł artystycznych (powieściach, poematach, dramatach, scenariuszach filmowych), niejawnie - w wypowiedziach zgodnych $\mathrm{z}$ konwencjami gatunkowo-stylistycznymi nauki. Swiadomość re-kreacyjnego charakteru działalności literaturoznawczej i jej performatywnej siły potwierdzają zarówno dokumenty zachowane w archiwach (listy, dzienniki, autobiografie, wspomnienia), jak samo ich pisarstwo. I takiej historii, która by wydobywała sprawczy, nie zaś czysto konstatujący status aktów literaturoznawczej mowy, pozornie jedynie referujących akty mowy literackiej, która by eksponowała ich wielofunkcyjność i związaną z tym wielojęzyczność oraz wielogłosowość, dziś potrzebują.

Świadczy o tym zużycie tradycyjnych „rzutów oka” na dzieje dyscypliny, porządkująco rozbijanej na szkoły i kierunki, metody i doktryny. Funkcjonują one $z$ pożytkiem na etapie propedeutycznym, jednakże wykładana w nich wiedza, którą gromadzą kompendia alfabetariuszowe i podręczniki, o „założeniach” i „metodach” kolejnych „kierunków”, podająca definicje „chwytu dezautomatyzacji” bądź „miejsc niedookreślenia”, „funkcji poetyckiej” czy „podmiotu lirycznego”, krótko mówiąc wiedza prezentowana wyłącznie w kontekście uzasadniania, pomijająca kontekst wyjaśniania, pozbawiona zaplecza ideowego, nieodniesiona do wartości, którym miała służyć, jest wprawdzie wyuczalna, niemniej pozostaje pusta lub fałszywa. Pusta - bo teoria literatury jest $w$ takich prezentacjach sprowadzana do wielości nawzajem podważających się ujęć, w których można albo dowolnie przebierać, wybierając doraźnie przydatne „słowniki”, albo je zlekceważyć. Fałszywa - bo upraszcza zróżnicowany literaturoznawczy modernizm do jednego, uniwersalnego „terroretycznego", wypreparowanego z neopozytywistycznej filozofii nauki i rozciągniętego następnie i na formalizm, i na fenomenologię, i na strukturalizm, i na semiotykę. Wobec tak rozumianej teorii faktycznie można być „przeciw”.

Można jednak spojrzeć na teoretyczne poszukiwania literaturoznawcze $\mathrm{z}$ innej perspektywy, by określić się wobec ich historii. O potrzebie zmiany punktu widzenia świadczy, po pierwsze, wspomniana na począt- 
ku nasilona refleksja o, jak" literaturoznawczych tekstów - o ich kształcie gatunkowym, ich poetyce i stylistyce. Pozwala ona doszukiwać się w tych tekstach nie tyle powierzchniowej „literackości”, ile przede wszystkim - odnaleźć w niej (właśnie jak w wypowiedzi literackiej) tropy, przez które uobecnia się ich podmiot i zaznacza kontekst, w którym powstały. O idącej w tym "chronotopowym" kierunku zmianie nastawienia wobec wypowiedzi literaturoznawczej świadczą też coraz bardziej intensywne $\mathrm{w}$ ostatnim ćwierćwieczu edycje archiwaliów (dokumentów autobiograficznych - listów, dzienników, wspomnień, samych autobiografii) i badania nad nimi, reedycje tekstów ujawniających konteksty narodzin koncepcji teoretycznych i rozległe studia nad nimi osadzające je wśród idei już nie tylko filozoficznych, naukowych i artystycznych, ale także społecznych, politycznych, ekonomicznych, studia nie pomijające również doświadczeń biograficznych ich autorów, jakie zostały poświęcone np. Lukácsowi, formalistom rosyjskim (Proppowi, Ejchenbaumowi, Brikowi), Jakobsonowi, Bachtinowi i uczestnikom jego „kół”, Ingardenowi i Łotmanowi. Działania obu typów sygnalizują, że tekst literaturoznawczy zaczyna coraz powszechniej być postrzegany jako wypowiedź, czyli tekst kultury.

O „chronotopowym zwrocie” badań nad historią teorii świadczą, po drugie, liczne dziś dyskusje o przedmiocie, metodach i zadaniach wiedzy o literaturze. Toczą się one równie intensywnie, jak na przełomie wieków, często też podnoszą na nowo owoczesne kontrowersje, poddając zasadniczej rewizji utrwalony stereotyp sfetyszyzowanej „orientacji estetycznej”. Spory o „przedmiot i metodę" nigdy zresztą nie znikły z pola uwagi nowoczesnego literaturoznawstwa; trwały także w jego deklarowanie antymetodologicznej fazie postteoretycznej, acz tu nie były tematyzowane w typowych formułach naukoznawczych.

Obserwowany dzisiaj renesans niegdysiejszych zatrudnień literaturoznawców i językoznawców, filozofów i estetyków, socjologów, psychologów i antropologów wymusiła szczególna sytuacja. W latach 20.-30., a potem 40., na obszarze środkowo-wschodnioeuropejskim, gdzie wspomniane spory były prowadzone najintensywniej, gdzie rodziło się nowoczesne literaturoznawstwo, zostały one zawieszone bądź po prostu brutalnie przerwane. Podjęte w latach 50.-60., w zupełnie jednak odmiennym kontekście (geograficznym i politycznym), postawione wobec najzupełniej innych tradycji intelektualnych i artystycznych, musiały doprowadzić do innego skonfigurowania norm określających wypowiedź literaturoznawczą i powinności przed nią stawianych niż w kontekście macierzystym. Gdy z kolei w późnych latach 60 . i początkowych 70. podejmowane na początku wieku dylematy znów znalazły się w polu uwagi już nie tylko literaturoznawstwa, ale i pozostałych nauk mających do 
czynienia $\mathrm{z}$ tekstami kultury, to ich naświetlenia były tak mocno skażone roztaczaną perswazyjnie w poprzedniej dekadzie wizją "estetyzmu" (strukturalizmu) bezprzymiotnikowego, reprezentującego "estetyzm” (strukturalizm) uogólniony - ową nienawistną „teorię”, dążącą jakoby do imperialistycznego samodzierżawia - że naturalną koleją rzeczy wywołały skrajnie liberalne reakcje, których efektem stały się właśnie aksjomaty „literaturyzacji” i „literackości” wiedzy, symptomatycznej dla nowej fazy postteorii. Miały one w latach późnych 60. i 70. tym większą siłę przebicia, że współbrzmiały $\mathrm{z}$ antyscjentystyczną, „rewolucyjną paradygmatyczną" w filozofii nauki i ze zaktywizowanym w jej wyniku nastawieniem pragmatyczno-konstruktywistycznym. Nastawienie to, wymierzone $w$ metodologię pozytywistyczną i neopozytywistyczną, która w literaturoznawstwie od dawna należała już do przeszłości, dostarczało podniet i autorytatywnego wsparcia dla antyteoretycznych ruchów również na jego obszarze.

Podsumujmy: w wyniku zawieszenia debat literaturoznawczych rozpoczętych we wczesnym modernizmie, spowodowanego głównie okolicznościami historyczno-politycznymi (likwidacją najpierw rosyjskiej szkoły formalnej i bliskich jej szkół lingwistycznych i kulturoznawczych, antropologii Bachtinowskiej i semantyki kultury Proppa i Freudenberg, potem zaś stratami wojennymi, powojennym zideologizowaniem projektów socjologiczno-kulturowych, osłabieniem i nie zawsze zinstytucjonalizowaną, ale jednak rzeczywistą delegalizacją strukturalizmu i fenomenologii), w wyniku dogmatyzacji i monologizacji tych debat, jakie następowało wraz $\mathrm{z}$ ich przeszczepieniem do odmiennej tradycji myślowej w latach 50.-60., wreszcie - na skutek rozminięcia się z nimi w końcu lat 60 . i na początku 70., gdy zamiast nich podstawiane były ich przykrojone wersje $\mathrm{z}$ poprzedniego dziesięciolecia, teraz jeszcze silniej redukowane stosownie do potrzeb antyteoretycznych kampanii, w których służyły za identyfikatory nagannego „esencjalizmu” i "fundacjonizmu” - w efekcie tego splotu przesunięć i pominięć literaturoznawstwo zostało rozdwojone na dwie fazy: modernistyczną i postmodernistyczną (nowoczesną i ponowoczesną). To właśnie z powodu przerwanej ciągłości (skądinąd zgodnej z modernistycznym myśleniem o dziejach w kategoriach „przełomów", myśleniem wzorowanym na naukach przyrodniczych, które jako wyłączne dostarczały materiału dowodowego nowej filozofii wiedzy), za rewelacje mogły zostać uznane „rewolucje paradygmatyczne”, które wyznaczyły antykartezjański paradygmat nowego naukoznawstwa i wyłonione w ich obrębie kolejne "zwroty” w samym literaturoznawstwie.

Myślenie w kategoriach „przełomów” usprawiedliwiało historyczną niepamięć. Dość jednak przypomnieć: Kuhnowskie „zmiany paradygmatów" wywodzą się wprost $\mathrm{z}$ koncepcji lwowskiego uczonego, Ludwika 
Flecka, a o „fakcie poznawczym” i rewolucyjnym przebiegu „ewolucji literackiej” wcześniej (i dla nas dogłębniej) niż Thomas Kuhn i Bruno Latour pisał Tynianow; $\mathrm{z}$ wypowiedziowej natury komunikatu językowego i kulturowej natury wypowiedzi rozumianej jako układ relacji tekst-kontekst daleko wcześniej (i dokładniej) niż szkoła brytyjska i amerykański poststrukturalizm zdawali sprawę Michail Bachtin, Walentin Wołoszynow i Olga Freudenberg, w językoznawstwie zaś - Jewgienij Poliwanow (który też odkrył dwoistą naturę fonemu i podwójny, konwergencyjno-dywergencyjny mechanizm zmian językowych na długo przed Martinetem). Odkrycie narracyjnej struktury rozumienia dokonało się w pracach Whadimira Proppa i Romana Ingardena. Nadto u Ingardena (podobnie jak u Mukařovskiego i potem Sławińskiego) przy tej okazji rozpoznana została radykalna niewspółmierność między linearnością narracji a symultanicznością zdarzeń w niej fingowanych i rekreowanych $\mathrm{w}$ odbiorze, tzn. rudymentarna trudność przejścia od zdania do tekstu (jednostek mikro i jednostek makro, w terminologii Poliwanowa); reader-response criticism wyważał drzwi otwarte $\mathrm{z}$ jednej strony przez fenomenologię i hermeneutykę, z drugiej - strukturalizm praski; (neo)pragmatyczne zerwanie więzi między tekstem a jego odczytaniami zwane anarchizmem interpretacyjnym doprowadziło jedynie do ekstremum dyskusje o intencji $\mathrm{i}$ interpretacji rozpoczęte $\mathrm{w}$ latach 20 . $\mathrm{i}$ intensywnie prowadzone w 40.-60. we wszystkich nurtach nawiązujących do hermeneutyki, w której też zanurzone jest głęboko (acz dyskontynuacyjnie) dekonstrukcjonistyczne wieczne mis-reading.

Poststrukturalistyczny "tekstowy świat" wyrasta z jednej strony z filozoficznej semiotyki Peirce'a, z drugiej zaś - z analiz Bachtina i semiotyków tartuskich, którzy podjęli Bachtinowskie rozpoznania; apologizowany obecnie $w$ różnych dyscyplinach relacyjny podmiot dialogowy z Bachtina/Woloszynowa krytyki freudyzmu oraz Lwa Wygotskiego rozważań o mowie wewnętrznej, w których także zawiera się projekt kognitywistycznych poszukiwań nad tekstowymi reprezentacjami mentalnych struktur poznawczych (podjęty przez Wiaczesława Iwanowa). Chaologiczną historiozofię poszukującą racjonalnego porządku $\mathrm{w}$ nieprzewidywalności śmiało można wyprowadzić z prac późnego Łotmana, $\mathrm{z}$ wczesnego zaś - Iserowską antropologię literatury; w krytyce etycznej wreszcie z jej dyskusją z kantyzmem i kluczowymi kategoriami („innego”, „odpowiedzialnej odpowiedzi”) - odnaleźć debaty prowadzone w Rosji przez filozofów sztuki Trzeciego Renesansu we wczesnych latach 10.-20., na teren filozofii literatury przeniesione przez Bachtina. Także coraz częściej przywoływane, niegdyś tylko teoriopoznawcze, kategorie doświadczenia i empatycznego przeżycia, w których polu lokuje się najnowsza koncepcja przedmiotu i podmiotu literaturoznawczego poznania, 
jawnie sięgają do schedy z przełomu wieków, to znaczy do pierwszej fazy wyłaniania się nowoczesnego literaturoznawstwa. W tej też fazie (u Poliwanowa, który całe życie pracował nad stworzeniem alfabetów dla języków azjatyckich) zainicjowane zostały rozważania nad możliwością językowego przekazu wielosensorycznych (akustycznych, wizualnych, gestowo-ruchowych) przeżyć poznawczych i świadomość, że ich reprezentacji służą zarówno suprasegmentalne jakości prozodyczne, jak ukształtowanie graficzne. Tu także, w kręgu Diltheyowsko-Bergsonowskiej filozofii sztuki, położone zostały podwaliny pod formułę czytanio-pisania, tzn. koncepcję literaturoznawczej lektury jako re-kreacji, tworzenia nowego tekstu, ożywioną w latach najpierw 60 . we francuskiej krytyce tematycznej, a potem twórczo podjętą w 70. w dekonstrukcji francusko-amerykańskiej.

Na przełomie wieków (w myśli Bergsona) i w pierwszych dziesięcioleciach wieku XX (u Wołoszynowa, Hopensztanda) pojawiły się wnikliwe analizy paralelizmu gramatyczno-ontologicznego i gramatyczno-socjologicznego, w których bierze początek radykalna krytyka opresywności języka, który „mówi nami”, narzucając własne kategorie gramatycznosemantyczne, substancjalizujące się i wywołujące efekt realności oraz wyznaczające wzorce postrzegania. Wtedy również, równolegle w filozofii języka i literatury i w samej sztuce literackiej, powstawały pierwsze (po romantyzmie) plany ucieczki $\mathrm{z}$,językowego więzienia", najczęściej bodaj sięgające po analogie $\mathrm{z}$ teoriami muzyki, powszechnie $\mathrm{w}$ modernizmie uznawanej za sztukę wyzwoloną z więzów semantyki, w których, jak się wydaje, zakorzeniona jest zarówno późniejsza problematyka „niewyrażalności”, jak krytyka „przedstawienia”, a także kategorie służące ich artykulacji („tonu”, „intonacji”, „głosu”). O nowej genologii, która sama odsłania Bachtinowskie korzenie, a tym bardziej o koncepcji intertekstualności, powszechnie wywodzonej z Bachtinowskiego dialogizmu, nie ma potrzeby przypominać.

Mówiąc ogólnie - nie wydaje się nadużyciem diagnoza, w której kolejne „Zw roty” dokonujące się w myśli o literaturze od 1966 roku (lingwistyczny, interpretacyjny, retoryczny, narratywistyczny, etyczny, kulturalistyczny), to kolejne pow roty. Podejmowały one problemy i sposoby ich konceptualizacji wypracowywane na długo przed tym pamiętnym rokiem. Radykalny francuski strukturalizm z fazy „Tel Quel”, który je inicjował, budowany na formalizmie i Bachtinie równocześnie, drugi, narratywistyczny renesans Proppa (po pierwszym, narratologicznym), drugie dokonane w poststrukturalizmie kulturalistycznym odkrycie Bachtina (po pierwszym, „dialogowym"), dekonstrukcjonistyczne i kognitywistyczne odsyłacze do fenomenologicznej intencjonalności - dostarczają $\mathrm{w}$ tej mierze dostatecznie silnych dowodów. Nie wydaje się też nadużyciem 
(ani odkryciem) diagnoza, iż spory o wiedzę literaturoznawczą z 2. połowy wieku podejmują raz jeszcze archetypiczny spór między zwolennikami tak ongiś (przez Kazimierza Wóycickiego) zwanych metod „wewnętrznych" i „zewnętrznych", rozpoczęty i prowadzony intensywnie w 1. połowie stulecia. Przemianowany dziś na spór między rzecznikami literaturoznawstwa „filologicznego" bądź „filozoficznego”, toczy się on wokół kwestii wartości „dowodowej” bądź „perswazyjnej” poczynań poznawczych, to jest ich rekonstrukcyjnego bądź konstrukcyjnego charakteru.

Toteż Druga Awangarda Literaturoznawcza - by tak nazwać badania literackie wchodzące na scenę nauki od około r.1966 - może być śmiało (nie inaczej niż malarska i muzyczna) wywiedziona $\mathrm{z}$ dokonań Awangardy Pierwszej, która rodziła się w Europie Srodkowo-Wschodniej w pierwszych dwóch dziesięcioleciach XX wieku. Jeśli ująć historię teorii literatury pod tym kątem widzenia, to formuly o jej „śmierci” w latach 90. XX wieku, o wyczerpaniu się jej sił witalnych lub, oględniej, o spełnieniu przez nią swojej „misji”, okażą się niecelne lub celne co najwyżej w odniesieniu do jej krótkiego (lat 50. i 60.) i ograniczonego (do obszaru francusko-anglojęzyczego) fragmentu. Nie inaczej niż formuła o „zwrotach" kulturalistycznym i antropologicznym, które miały nastąpić na początku lat 90. , ratując odchodzącą teoretyczną wiedzę o literaturze, i wspomniana na początku diagnoza „literaturyzacji” tej wiedzy, wypierającej jej dotychczasowe ukształtowanie dyskursywne. Te bowiem przeobrażenia już się dokonały - w projektach i badaniach literaturoznawców z pierwszoawangardowej generacji.

Nie znaczy to jednak ledwo: nihil novi..., acz, jak zwykle w dziedzinach wiedzy rozwijających się kumulatywnie, w których teoria i praktyka są zawsze ułomną pamięcią o własnej historii, a prekursorstwu i innowacjom daleko do wyrazistości. Wprawdzie idee uznawane za główne wyróżniki literaturoznawstwa ponowoczesnego tkwią korzeniami w literaturoznawstwie nowoczesnym, niemniej - już tylko $\mathrm{z}$ uwagi na zmieniony kontekst przyswojenia, inny „chronotop” - różnią się od nich na tyle, że nie sposób ich zbyć uznaniem za duplikat pierwszych. Różnica rzucająca się w oczy od razu polega na specyfice renesansu koncepcji wypracowanych na terenie wschodnio- i środkowoeuropejskim, gdzie literaturoznawstwo się rodziło, dezawuowanych potem i zapominanych (jak wczesna hermeneutyka), marginalizowanych (jak Ingardenowska fenomenologia) bądź kontynuowanych w tak zmutowanej i zredukowanej postaci (jak rosyjski formalizm, antropologia Bachtina, semantyka kultury Proppa), że trudnych do rozpoznania.

Odrodzenie i „wywyższenie” tej, jak to celnie nazwał Tynianow dla historii literatury, „młodszej linii” literaturoznawstwa z 1. połowy wieku nie tylko bowiem odcisnęło znaczący ślad na problematyce podejmo- 
wanej w połowie drugiej, decydując wręcz o dokonujących się najważniejszych przewartościowaniach i przemianach, nie jedynie przy tym w domenie literaturoznawstwa, ale we wszystkich bodaj dziedzinach nauki o kulturze. Równie ważna jak odrodzenie tych koncepcji, poruszanych w nich tematów i problemów, wypracowanych terminów (niekiedy zresztą przekształconych do niepoznaki) jest bowiem rewitalizacja powstałych wówczas zróżnicowanych form wypowiedzi literaturoznawczej.

Whaśnie w 1. połowie wieku rodziła się literatura literaturoznawcza, czyli taki typ dyskursu naukowego, który świadomie, w opozycji do form usankcjonowanych w nauce oficjalnej, stawiał na zespolenie jego funkcji poznawczych $\mathrm{z}$ przypisywanymi sztuce literackiej, performatywnymi. Narodzinom tej literatury (eseistycznej, powieściowej, dramaturgicznej, epistolarnej, konfesyjnej - diarystycznej i autobiograficznej) towarzyszyło przy tym, jak świadczą otaczające ją lub w nią wpisane odautorskie komentarze, doskonałe rozpoznanie alternatywności przemycanego kontrabandą projektu wiedzy (nazywanej też „innowiedzą" lub „innonauką") wobec zastanego, inercyjnie powielanego i uznawanego za obowiązujący. Tego typu literatura naukowa znalazła się w centrum dyskursu uznawanego za ponowoczesny, wyznaczając jego prototyp. Rezonans, jaki wywołała, był radykalnie odmienny niż w 1. połowie stulecia, kiedy nie zyskała ona akceptacji jako jeden $z$ literaturoznawczych dyskursów możliwych, gdy nie przywiązywano do niej większej wagi lub ją pomijano. $\mathrm{O}$ ile $\mathrm{w} 1$. połowie wieku stanowiła margines, o tyle w połowie 2 . znalazła się w centrum.

Różnica druga polega na usankcjonowaniu i wzmocnieniu międzymetodologicznego i międzydyscyplinowego współdziałania i związanego $\mathrm{z}$ tym zawieszenia sporów o dyscyplinowo-metodologiczną dominację. Wprawdzie, wbrew przypisywaniu 1. połowie wieku nastawienia separatystycznego, znamionującego jakoby przełom antypozytywistyczny, kiedy to literaturoznawstwo miało wybijać się na niepodległość, transnaukowa wymiana idei i języków wtedy właśnie była szczególnie intensywna, była to jednak wymiana jednokierunkowa (inspiracje płynęły z nauk ościennych do literaturoznawstwa) i binarna (zwykle współdziałały ze sobą dwie dyscypliny). Przejawami takiej kooperacji są nie tylko najbardziej wyraziste i najlepiej znane: infiltracja filozofii (w fenomenologii, hermeneutyce, w koncepcji Bachtina) i lingwistyki (w formalizmie, strukturalizmie i semiotyce, zarówno tartuskiej, jak generatywnej). Równie silny udział w kształtowaniu się nowoczesnego literaturoznawstwa miały też nowoczesne nauki tzw. ścisłe, rodzące się wtedy równocześnie $z$ humanistycznymi. Widać to dobrze w słowniku antypozytywistycznych propozycji, który zapożyczał swoje terminy z nowej biologii 
i fizyki równie często, jak z historii sztuki i muzykologii. Nie jest przypadkiem, że w pracach i Bachtina $z$ lat 30., i Kridla $\mathrm{z}$ tego samego okresu przedmiot badań literackich był prezentowany właśnie w języku fizyki poeinsteinowskiej, a Propp opatrywal rozdziały Morfologii bajki mottami z Goethego, demonstrując zbieżność przyrodoznawczego i językoznawczego pojmowania struktury. Formujące się dopiero koncepcje literaturoznawcze dobrze rozpoznawały zbieżność swych zamierzeń z krystalizującymi się ujęciami procesu poznania i jego przedmiotu w antypozytywistycznych naukach o przyrodzie. Ówczesna wiedza o literaturze nie tyle zatem odgradzała się od innych dyscyplin uzurpując sobie przywilej autonomii, ale raczej obierała którąś z nich za nadrzędny, rozstrzygający układ odniesienia. Znaczną część zażartych dyskusji między zwalczającymi się nawzajem różnymi kierunkami badań literackich z 1. połowy stulecia sprowadza się właśnie do sporów o to, którą z ościennych nauk uznać należy za "gospodarza/żywiciela".

W 2. polowie wieku czas wojen, kampanii, potyczek, batalii o dyscyplinę wspierającą - by użyć zmilitaryzowanej retoryki symptomatycznej dla 1. połowy wieku - przeszedł do historii. Rozbrzmiewające jeszcze od czasu do czasu „zatargi graniczne" należą do tej, uznającej granice i kompetencyjną wyłączność, przeszłości. I jeśli agonalna retoryka militarystyczna bywa na nowo przywoływana w sukurs (jak w niedawnej kampanii antyteoretycznej), to jej efekty znikają z pola uwagi równie szybko, jak się pojawily. Rozpoznanie „kulturowej natury” literatury, jak to zostało odkrywczo, z trafnością właściwą aforystycznemu oksymoronowi nazwane, a z drugiej strony „literackiej natury” kultury pozwoliło zawiesić jątrzące ongiś pytania o dyscyplinowe kompetencje i monopol na opis i interpretację wypowiedzi literackiej oraz uprzywilejowaną, królewską metodę gwarantującą osiągnięcie „prawdy" o niej.

A dokładniej - nie tyle zawiesić, co podjąć niegdysiejsze transdyscyplinowe (literaturoznawczo-filozoficzne i literaturoznawczo-lingwistyczne, literaturoznawczo-przyrodoznawcze) praktyki i nadać im nową jakość, tzn. wyłonić się i okrzepnąć antropologii literatury. Antropologia ta różni się znacznie od tej, jaka była proponowana w latach 50.-60. w szkole brytyjskiej i amerykańskiej, a nawet francuskiej. Jest bowiem integralną transdyscypliną, która tyle samo zawdzięcza wiedzy o świecie pozaliterackim, co do niego wnosi. W centrum swojej uwagi umieszcza bowiem wypowiedź rozumianą jako nośnik światopoglądu (ideologii, filozofii), który nie odwzorowuje (nawet ,homologicznie”) domniemanego pozatekstowego świata, lecz go aktywnie wytwarza. Śladów tej aktywności rzecznicy ponowoczesnej antropologii upatrują w ukształtowaniu dyskursu, podejmując tym samym najciekawsze dokonania literaturoznawstwa nowoczesnego - fenomenologicznego i hermeneutycznego, bach- 
tinowsko-wołoszynowskiego, słowiańsko-stukturalistycznego. Nie rezygnując więc $z$ najważniejszych dla 1. połowy stulecia pytań (o specyfikę tekstu, języka, podmiotu) czytają i podejmują proponowane wówczas rozstrzygnięcia $\mathrm{w}$ odmiennym układzie odniesienia, zespalając punkt widzenia "dośrodkowy” $\mathrm{z}$ „odśrodkowym”, skupieni na tym, co „literackie" (na niepowtarzalnych poza literaturą, swoistych dla niej mechanizmach organizacji znaczenia i niesionego przez nie poznania) - ale uznają ową „literackość” za funkcję podmiotowych działań kulturowych, zarówno autorskich, jak czytelniczych. Nadto owa niepowtarzalność nie jest już traktowana jako dewiacja języka poetyckiego, zdefektowanego w porównaniu $\mathrm{z}$ językiem niepoetyckim, o ważkich wprawdzie funkcjach poznawczych (zgodnie z zasadą: anomalia pozwalają dojść do prawidłowości), ale jednak dewiacyjnego. Cechuje ona wszelką, także pozajęzykową, pracę umysłu, którego działanie jest dziś przedstawiane jako właśnie „poetyckie”. Coraz intensywniejsze i coraz bardziej wiarygodne odkrycia „poetyki umysłu” silnie podbudowują tę transdyscyplinową kooperację.

Różnica trzecia polega na zasygnalizowanej już zmianie statusu dyskursywnego wypowiedzi uznawanej za literaturoznawczą. Zmiany tej nie sposób jednak sprowadzić do przytoczonej na początku (z jawnym dystansem) formuly literaturyzacji wiedzy, symptomatycznej jakoby dla fazy „post”. Formuła ta w ogóle nie wydaje się najszczęśliwsza. Po pierwsze dlatego, że została ukuta na mocy kontrowersyjnych, historycznie jedynie ważnych kryteriów wyodrębniających wypowiedź tak „naukową", jak „literacką" (mówiąc dokładniej - jej celność ogranicza się do neopozytywistycznej koncepcji nauki i towarzyszącej jej wysokoestetycznej koncepcji literatury). Po drugie dlatego że - nawet jeśli przyjąć tę formułę $z$ dobrodziejstwem inwentarza - rozpoznawana na jej mocy „literaturyzacja" nie dotknęła literaturoznawstwa nagle, wraz z przełomem półwiecza. Zarówno w 1., jak 2. połowie stulecia było ono dalekie od monofonii ideowej (metodologicznej) i stylistycznej. Profesorskiej powieści literaturoznawczej nie wymyślił ani Dawid Lodge, ani Umberto Eco, ani tym bardziej liczna rzesza ich następców, literaturoznawczej autobiografii Roland Barthes ani tym bardziej Helen Cixous. Od niepamiętnych zgoła czasów badacze literatury „drugą ręką" składali poematy i dramaty; William Empson, Roman Jakobson, Anna Burzyńska nie stanowią pod tym względem precedensu.

Między poematami filozoficznymi Empedoklesa, poetologicznymi komediami Arystofanesa, średniowiecznymi dialogami o literaturze, trzynastozgłoskowcem zapisaną Sztuką rymotwórczq Dmochowskiego i roman à clef Schlegla Lucinde a późniejszą twórczością uczonych nie sposób oczywiście postawić znaku równości. Te pierwsze powstawały 
w epoce, gdy nauka jeszcze się instytucjonalnie nie wyodrębniła, nie została też ujęta w metodologiczne ryzy. Trudno w takiej sytuacji mówić poważnie $i$ bez anachronizmów o jej literackim piętnie. Pod tym względem wiek XX faktycznie wymaga osobnej uwagi. Ale, jak już zostało powiedziane, cały wiek XX, nie zaś jedynie jego druga połowa. „Dwuręczna”, by użyć określenia Jerome Brunera, czy lepiej - dwugłosowa, literacka i naukowa, twórczość badaczy literatury wyróżnia zarówno jego fazę wczesnomodernistyczną (lata 10.-30.), jak dojrzałą (lata 40.-60.) i późną (lata 70.-90.). Z tej środkowej wydaje się nawet najbardziej godna wyeksponowania, bo uprawiali ją badacze, którzy stanowczo jakoby i nieprzejednanie opowiadali się za nauką jako czystym poznaniem i literaturą jako sztuką autonomiczną. We wszystkich trzech fazach powstawały też wypowiedzi, które, acz uznawane za literaturoznawcze (teoretycznoliterackie) i jako takie włączane do instytucjonalnego akademickiego obiegu, jawnie nie spełniały rygorów stawianych wypowiedzi naukowej (referencji do świata niezależnego od świadomości i języka, decydującej o ich niefikcyjności, czyli weryfikowalności wedle korespondencyjnej koncepcji prawdy, neutralności i jednoznaczności języka, logiki argumentacji i wyczerpywalności wspierających ją danych, apodyktycznej konkluzywności). Języka tych wypowiedzi nie sposób uznać za przedmiotowy, a ich autorom przypisać stanowisko monologowe. Ta, by tak określić, jednoręczna, głęboko polifoniczna i wielostronnie zdialogizowana twórczość badaczy literatury, niepodpadająca pod ustalone kryteria wypowiedzi naukowej, choć jak naukowa, tj. roszcząca sobie ambicje poznawcze i faktycznie funkcje poznawcze spełniająca, także znamionuje cały wiek XX. Krótko mówiąc, w wieku tym dyskurs uznawany za literaturoznawczy był równie zróżnicowany, jak ten uznawany za literacki.

Jeśli więc $\mathrm{w} 2$ 2. połowie wieku XX zaszła zmiana, którą dałoby się określić mianem "literaturyzacji”, to nie ze względu na wysyp wypowiedzi dwuręcznych i dwoistych, trudnych do jednoznacznego uznania za bądź naukowe, bądź literackie, lecz zmianę podejścia do nich. $\mathrm{O}$ ile $\mathrm{w} 1$. połowie wieku były one $\mathrm{w}$ najlepszym razie uznawane $\mathrm{za}$ "wypadki graniczne", to w połowie drugiej mogły już legalnie znaleźć się w obiegu naukowym na równych prawach, jak prototypowo naukowe. Zmiana ich usytuowania nie dokonala się wszakże uznaniowo, w efekcie prostego rozpoznania w wypowiedzi naukowej-jakości literackich, przyłożenia do nich koncepcji ,języka poetyckiego" i odnalezienia w nich realizacji „funkcji estetycznej”. Status wypowiedzi w ogóle nie jest jej własnością absolutną, pozahistoryczną. Kryteria, na których podstawie najpierw próbowano odróżnić naukę od literatury, a potem je zrównać, kształtowały się i różnicowały ze względu na inne kryteria, w zmiennym polu odniesienia do kategoryzacji podsuwanych przez aktualną filozofię (bytu, 
poznania, podmiotu, wartości), filozofię nauki, lingwistykę, semantykę, tekstologię, genologię i stylistykę, retorykę, wreszcie - samą sztukę. Jeśli wziąć $\mathrm{w}$ nawias te historyczne uwikłania i je pominąć, wówczas formuła literaturyzacji wiedzy pozostaje równie pusta, jak ongiś - estetyczności literatury. Takie ahistoryczne i akontekstowe nastawienie, kierujące się przekonaniem o istnieniu ,jednej" wiedzy i ,jednej” literatury, prowadzić może wręcz do absurdów. Jak - by wyręczyć się przykładami - doszukiwanie się w Kartezjuszowej Rozprawie o metodzie wyznania-autobiografii - z jednej strony, z drugiej zaś - odrzucenia autobiografii Ignacego Chodźki (co się zdarzyło Wacławowi Borowemu), gdyż złożona $\mathrm{z}$ samych cytatów nie licuje $\mathrm{z}$ formułą rozprawy dokumentacyjno-faktograficznej, jaką powinna być autobiografia.

Formułę literaturyzacji wiedzy o literaturze można jednak także rozumieć inaczej - jako nazwę takiego podejścia do wypowiedzi naukowej (to jest uznawanej na mocy niepisanego paktu poznawczego w określonej wspólnocie i w określonym czasie za naukową), jak do wypowiedzi uznawanej za literacką. Do, jednym słowem, ujmowania obu jako wypowiedzi właśnie, określanej przez to, kto, gdzie, kiedy, po co, do kogo i w jaki sposób mówi. Dla literatury (polskiej) owocność takiego podejścia, uwzględniającego zarazem aspekt syntaktyczny, semantyczny i pragmatyczny tekstu, nie budzi już kontrowersji, przyniosło też ono ważkie efekty. Najistotniejszy $\mathrm{z}$ nich to wykrystalizowanie historycznoliterackiej formacji modernistycznej $\mathrm{i}$ wyodrębnienie $w$ niej czterech równorzędnych dyskursów, które promieniuje także na rozpoznanie procesu historycznoliterackiego $\mathrm{w}$ innych epokach. Dla nauki podobną perspektywę otwarły przemiany w naukoznawstwie, które od lat 60 . wstrząsały jego oficjalnym „normalnym” światem. Zapowiadały ją inspiracje płynące $\mathrm{z}$ filozofii języka (Austina, Wittgensteina i Bachtina), z semantyki kognitywnej (szczególnie, acz nie tylko, z badań nad metaforą), $z$ rozważań o procesie twórczym $w$ nauce intensywnie prowadzonych w psychologii poznawczej, z podjętych w tzw. krytyce genetycznej analiz rękopisów uczonych, z zainicjowanych w różnych środowiskach serii ich autobiografii, edycji dzienników, korespondencji i innych materiałów dotąd interesujących jedynie socjologów i badaczy życia literackiego. Ich zwieńczeniem jest rodząca się na naszych oczach antropologia wie$\mathrm{dzy}$, w której te różnokierunkowe poszukiwania winny znaleźć integrujące wsparcie.

W odniesieniu do literaturoznawstwa konieczność takiego jednolitego podejścia do obu typów wypowiedzi, literackiej i literaturoznawczej, rozpościerających się $\mathrm{w}$ polu między dwoma hipotetycznymi, ale rzadko tylko osiąganymi skrajnymi biegunami, podpowiada cała jego $\mathrm{XX}$-wieczna historia. Znamienne są w niej zwłaszcza dzieje sporów o „literackość”, 
zawsze definiowaną relacyjnie - ze względu na „nieliterackość”, reprezentowaną przede wszystkim właśnie przez „naukowośč”. Taką konieczność potwierdza także analiza dziejów lektury i interpretacji tekstów uznawanych za literaturoznawcze - wszystkich niekończących się dyskusji o ich „właściwy” sens, o „prawdziwe” znaczenie proponowanych w nich terminów, równie nierozstrzygalnych, jak w przypadku tekstów literackich. Nie inaczej niż literackie, również teksty literaturoznawcze obrastały tymi dyskusjami-konkretyzacjami, nie do wydobycia spod nich, często też pozostał z nich (jak i z literackich) obszerny zbiór opowieści, uchodzących za rekonstrukcje. Wskazują na taką konieczność także studia nad przekładami wypowiedzi naukowych; mutacje, jakie przy tym zachodzą, także w warstwie terminologicznej, dowodnie wskazują, że rzekomo transparentny język naukowy podlega takim samym prawom, jak metaforyczny, symboliczny i wieloznaczny język uznawany za literacki. Przekonują do takiej potrzeby również porównania kolejnych edycji wielu prac literaturoznawczych, okaleczanych (cenzurowanych, modyfikowanych) tak jak literackie i z podobnych powodów, najmniej związanych $\mathrm{z}$ „prawdą" o na pozór obiektywnie przedstawianych w nich „dziełach". Poświadczają - losy samych badaczy, których książki bywały uznawane za równie niebezpieczne, jak literackie i z tego powodu wespół z poetami wyganianych $\mathrm{z}$ państw bądź skazywanych na wieloletnie milczenie. Bez uwzględnienia ich biografii historia dyscypliny wyradza się w „historię nauki bez nazwisk”, w historię podatnych na instrumentalne traktowanie „doktryn” i „metod”, co wybitnie unieczytelnia XX-wieczne pisarstwo literaturoznawcze. Kwestia podmiotowości wypowiedzi naukowej wydaje się zresztą w ogóle dzielić podobne koleje losu, jak wypowiedzi literackiej. W przypadku obu pojawiają się podobne problemy: autorstwa niepewnego, autorstwa kolektywnego, w obu też ewolucja podmiotu twórczego polega na stopniowym przechodzeniu od podmiotu monologowego do dialogowego i coraz silniejszym eksponowaniu jego obecności, niesprowadzalnej już tylko do imiennej sygnatury.

O zasadności jednolitego podejścia do wypowiedzi literackiej i literaturoznawczej przesądza także sama literatura, która w co najmniej jednym modernistycznym wariancie sukcesywnie zacierała granice między fikcyjnym tekstem i refleksyjnym komentarzem, językiem i metajęzykiem, wyobraźnią artystyczną i naukową. Rzecz tu w dobrze rozpoznanym zjawisku autotematyzmu, ale także np. w teoretycznych wykładach, stanowiących integralny komponent samych utworów (jak u Karpowicza czy Wirpszy, którzy nawet posługiwali się formami wypowiedzi charakterystycznymi właśnie dla komentarza: cytatem, przypisem), w towarzyszących utworom esejach i diariuszach, w których te pierwsze znajdują nieodzowne dopełnienie (Gombrowicz), wreszcie - we wprowadzaniu 
kwestii literaturoznawczych jako tematów literackiej obróbki (Białoszewski, powieść krytycznoliteracka młodszego i najmłodszego pokolenia - Pawła Dunina-Wąsowicza, Krzysztofa Vargi, Jana Sobczaka, i tzw. powieść kulturoznawcza - Doroty Masłowskiej, Mirosława Nahacza). Tematyzacja literaturoznawstwa w literaturze przejawia się także w sytuowaniu jego twórców jako bohaterów literackich (u Manueli Gretkowskiej, Joanny Bator, Marka Bieńczyka, w znaczącej liczbie powieści, dramatów i liryków, których bohaterami byli Bachtin, Wołoszynow, Szkłowski, Poliwanow). Międzydomenowe przemieszczenie polega w tych utworach na tym, że to nie teoria komentuje literaturę, ale literatura - teorię (jak u Davida Lodge'a i Umberta Eco, a wcześniej - Konstantina Waginowa, Wieniamina Kawierina, Wiktora Szkłowskiego). Wydaje się zresztą, że podobna strategia budowania znaczeń jest znamienna nie tylko dla modernistycznej literatury, ale także innych sztuk. Ich kolażowo-montażową, pastiszowo-persyflażową cytatowość (jak u Tadeusza Kantora) wielotworzywowość (jak w obrazach-reliefach i suprematach Kazimierza Malewicza, asamblażach i architektonach Lubow Popowej i Władimira Tatlina, fotomontażach El Lissitzky'ego) - z jednej strony, z drugiej zaś programowe zacieranie granic między wytworem artystycznym a przedmiotem realnym (już-gotowym) lub wytworem artystycznym a refleksyjnym komentarzem do niego (w konceptualizmie), eksponowanie procesu twórczego, nie zaś jego wytworu (w informelu), wydobywające niefinalność, niedefinitywność rezultatu, można uznać za wyraziste odpowiedniki nastawienia sztuki literackiej i literaturoznawczej.

Przede wszystkim jednak o zasadności i konieczności wypracowania takiego jednolitego podejścia do wypowiedzi literackiej i literaturoznawczej przesądza zróżnicowanie pisarstwa literaturoznawczego, w całym modernizmie, jak już powiedziano, równie wielokształtnego, wielogłosowego i wielojęzycznego, jak literackie. Istotne wydaje się zwłaszcza to, że w bogatym repertuarze tekstowych form pretendujących do pełnienia funkcji poznawczej, których dopracował się literaturoznawczy modernizm, miejsce eksponowane i najbardziej bodaj reprezentatywne dla jego światopoglądu zajmują wypowiedzi drugiego stopnia, tzn. wypowiedzi naśladujące formy i style zarezerwowane w normatywnych prototypach dla literatury (oraz innych rodzajów sztuk, muzyki i plastyki), dla dokumentu osobistego (autobiografia) i dla publicystyki (wywiad, felieton, polemika). Znajdziemy wśród nich dialog i trialog (Ryszard Przybylski, Maria Janion) i liczne wielogłosowe utwory zbiorowego autorstwa, epistolarną powieść teoretycznoliteracką (Szkłowski), fragmentaryczne "zapiski" teoretycznoliterackie stylizowane na poetyckie „zapiski” czy „zanoty” (Sławiński), powieść historycznoliteracką (Aniela Gruszecka, Jarosław Marek Rymkiewicz) i krytyczną parodię takiej po- 
wieści (Włodzimierz Bolecki), historycznoliteracki dramat (Krzysztof Rutkowski), autobiograficzne solilokwium (Stefan Szymutko) i autobiograficzną sylwę (Edward Balcerzan), złożone z komentowanych cytatów wyznanie badacza (Michał Paweł Markowski), anty-słownik i anty-encyklopedię (Rymkiewicz). Wypowiedzi te mają charakter sui generis dialogowy - aluzyjnie przywolując swoje literackie, naukowe, publicystyczne i potoczne poprzedniki, stylizując się na nie, a tym samym wobec nich dystansując - wchodzą $\mathrm{w}$ złożone relacje $\mathrm{z}$ wpisanymi $\mathrm{w}$ nie światopoglądami.

Niezależnie od tego, czy poprzedniki te są traktowane na zasadzie aluzji, stylizacji, pastiszu czy krytycznej parodii, przywoływane serio czy też ironicznie, ich semantyka kształtuje się tak jak w każdej wypowiedzi dwu- i wielogłosowej - na tej więc zasadzie, jaka stała się wyróżnikiem literatury modernistycznej w jej najbardziej nośnym nurcie: polifonicznym, po Bachtinowsku „upowieściowionym”. Na tak rozumianym u-powieściowieniu polega, jak się zdaje, rzeczywista literaturyzacja wiedzy o literaturze; powierzchniowe jakości stylistyczne („piękno stylu”, obecność tropów i figur retorycznych, fabularyzacja wywodu, narracyjny charakter wykładu), a nawet „drugą ręką" pisane powieści nie odgrywają pod tym względem większej roli. Dawid Lodge, Umberto Eco, Michał Głowiński, Zofia Mitosek pozostaną uczonymi, jakkolwiek wiele wielowątkowych fabuł jeszcze napiszą, podczas gdy Bachtin, Wiktor Szkłowski, Dymitr Szostakowicz, Mieczysław Porębski oraz niektórzy krytycy etyczni będą „powieściopisarzami”. Powieść bowiem to „tekstowy Robin Hood", jak ją nazwal bachtinolog: rozsadza ona światopogląd oficjalny (tak literacki, jak naukowy), wprowadzając do niego obce mu, uznane za hierarchicznie niższe (gorsze) lub niestosowne, niegodne sposoby mówienia. Za ich sprawą inicjuje reorientację wszystkich jego składników - podejmowanych tematów i problemów, przekonań o ich ważności, sposobów ich ujmowania, autorytetów, w których obliczu są rozstrzygane. Pozwala też podjąć takie tematy i problemy, których inne, nie-powieściowe artykulacje nie mogły dostrzec. Tak właśnie jak naukowa wiedza o literaturze wprowadzając do swego organizmu „gorsze” formy poznania, tj. literaturę $\mathrm{i}$ inne sztuki, a tym samym dokonująca odczarowania wiedzy wysokiej.

Powieściowa polifonizacja bowiem, trzeba to mocno podkreślić, tak w literaturze, jak w literaturoznawstwie, sięga nie jedynie stylu pisarskiego, ale teź stylu myślowego. Właściwe modernistycznej wypowiedzi literaturoznawczej zdialogizowanie: zewnętrzne (którego manifestacją są polemiczne wstępy, „stany badań", przypisy, „ekskursy” i bibliografie) oraz zdialogizowanie wewnętrzne (przejawiające się w sposobach referowania cudzego stanowiska, w stylistycznych aluzjach, ukrytych cytatach, 
paronomastycznych przekształceniach, niesygnowanych osobowo, ale czytelnych odnośnikach do poprzedzających wypowiedzi - jak wyrażenia typu „a jednak”, „tymczasem”, które presuponują to inne stanowisko, we wskaźnikach wewnętrznej polemiki prowadzonej przez podmiot poznania z samym sobą, takimi jak dystansujące zdania wtrącone, wyrażenia ujęte $\mathrm{w}$ cudzysłów, intonacyjne ironiczne i autoironiczne wtręty i wiele innych chwytów $\mathrm{z}$ bogatego, repertuaru sygnałów dialogu wewnętrznego) - zdialogizowanie to wskazuje, że jej autor zajmuje postawę poznawczą wieloperspektywicznie zmienną. Ten jego świadomie niestabilny punkt widzenia, powstrzymujący skutecznie definitywność rozstrzygnięć, w perspektywie poetologicznej reprezentuje racje dramatu, w perspektywie epistemologicznej zaś - racje dialogowo pojmowanego poznania i dialogicznie nastawionego wobec jego wyników podmiotu. Także pod tymi względami wypowiedź literaturoznawcza nie różni od literackiej obie dążą raczej do przedstawienia komplikacji prawdy (doświadczenia, przeżycia) niż jej ujednoznacznienia, do przedstawienia dramatycznego procesu poznawczego, a nie narracyjnego wytłumaczenia jego wyników. Jakkolwiek więc na powierzchni wypowiedź literaturoznawcza przyjmuje zwykle kształt narracji, rzadziej uciekając się do form jawnie anarracyjnych i rzadziej niż literatura podejmując otwartą walkę z linearnością języka, która tamuje ekspresję nielinearności poznania, to z narracyjnością jako strukturą poznawczą (monologową teleologią i finalistyczną konkluzywnością) prezentowana w niej wiedza nie ma wiele wspólnego.

Dramaturgiczna wypowiedź literaturoznawcza nie jest mimo to tożsama ze swoim literackim odpowiednikiem. Postulowane ujednolicenie podejścia do wypowiedzi literackiej i literaturoznawczej nie oznacza zacierania granic między nimi ani tym bardziej ich utożsamiania. Obie one różnią się $\mathrm{z}$ uwagi na persony dramatu. $\mathrm{O}$ ile w wypowiedzi literackiej zewnętrzny i wewnętrzny dialog światopoglądowy autora może zostać rozpisany na głosy postaci zarówno realnych, jak fikcyjnych, jednorazowo wprowadzanych na scenę poznania, to w wypowiedzi literaturoznawczej dialog taki jest możliwy jedynie pomiędzy głosami realnych „innych”. Także „scena”, na której toczy się ów zewnętrzny i wewnętrzny dialog, umieszczona jest $\mathrm{w}$ realnej czasoprzestrzeni społeczno-komunikacyjnej, tzn. w chronotopie rzeczywistym. Toteż wypowiedź literaturoznawcza pozostaje wypowiedzią niefikcjonalną; jej stylizacja na wypowiedź fikcyjną niczego pod tym względem nie zmienia. Na tym, jak się wydaje, polega nieprzekraczalna różnica między literaturą i literaturoznawstwem. Pozostałe - sprowadzają się do historycznie zmiennych paktów poznawczych, lokalnie respektowanych norm i konwencji, które powstają $w$ efekcie przypieczętowywanych instytucjonalnie negocjacji, stabilizujących prototypy „literatury” i „nauki o literaturze”. 